\title{
Knowledge of Health Professionals on Essential Newborn Care in Bamako, Mali
}

\author{
Fatoumata Dicko Traoré1*, Mariam Sylla1, Hawa Diall1, Mamadou Traoré2, Pierre Togo1, \\ Mariam Maïga ${ }^{3}$, Nouhoum Lalama Traoré4, Leyla Maïga1, Kalirou Traoré1, Marikomossé Sacko1, \\ Souleymane Sagara1, Hamadou Ibrahim¹, Oumou Maïga1, Diakaridia Mariko3, Saoudatou Tall5, \\ Oumar Coulibaly ${ }^{1}$, Issiaka Koné1, Modibo Soumaré6, Kadiatou Ba7, Youssouf Traoré8, \\ Niani Mounkoro ${ }^{8}$, Toumani Sidibé ${ }^{1}$
}

\author{
${ }^{1}$ Department of Pediatrics, CHU Gabriel Touré, Bamako, Mali \\ ${ }^{2}$ Reference Health Center of Commune V, Bamako, Mali \\ ${ }^{3}$ Reference Health Center of Commune VI, Bamako, Mali \\ ${ }^{4}$ Reference Health Center of Commune IV, Bamako, Mali \\ ${ }^{5}$ Reference Health Center of Commune III, Bamako, Mali \\ ${ }^{6}$ Reference Health Center of Commune I, Bamako, Mali \\ ${ }^{7}$ Reference Health Center of Commune II, Bamako, Mali \\ ${ }^{8}$ Department of Gynecology and Obstetrics, CHU Gabriel Touré, Bamako, Mali \\ Email: *fatdickoped@gmail.com
}

How to cite this paper: Traoré, F.D., Sylla, M., Diall, H., Traoré, M., Togo, P., Maïga, M., Traoré, N.L., Maïga, L., Traoré, K., Sacko, M., Sagara, S., Ibrahim, H., Maïga, O., Mariko, D., Tall, S., Coulibaly, O., Koné, I., Soumaré, M., Ba, K., Traoré, Y., Mounkoro, N. and Sidibé, T. (2018) Knowledge of Health Professionals on Essential Newborn Care in Bamako, Mali. Open Journal of Pediatrics, 8, 311-323. https://doi.org/10.4236/ojped.2018.84032

Received: October 27, 2018

Accepted: November 30, 2018

Published: December 3, 2018

Copyright $\odot 2018$ by authors and Scientific Research Publishing Inc. This work is licensed under the Creative Commons Attribution International License (CC BY 4.0).

http://creativecommons.org/licenses/by/4.0/ (c) (i) Open Access

\begin{abstract}
Despite existing policies on training health professionnels in essential newborn care (ENC), neonatal mortality still remains high in Mali. Our work aimed to assess the level of knowledge of health staff about ENC. Material and methods: From March $20^{\text {th }}$ to April $20^{\text {th }}, 2016$, we interviewed newborn care providers at the six reference health centers and the Gabriel Touré University Hospital Center in Bamako. Results: In total, we interviewed 407 newborn care providers with a sex ratio of 0.52 . Interviewees had over five years work experience in $62.1 \%$. They considered a low Apgar score as an indication for neonatal resuscitation in $89 \%$, regardless of profile $(\mathrm{p}=0.1583)$. They knew the good aspiration technique in 54\%, with nurses and midwives more knowledgeable $(\mathrm{p}<0.001)$ of the reference health centers $(\mathrm{p}=0.0000)$. The interviewees knew the indication and rate of ventilation in $30.2 \%$ and $16.0 \%$, respectively. About one third (34\%) thought oxygen administration should be systematic during ventilation. The knowledge level on ventilation was the lowest in the group of general practitioners $(p=0.0063$ for oxygen indication and $\mathrm{p}<0.001$ for the technique). Knowledge level for other ENC components (temperature maintenance, eyes care, breastfeeding) were higher. The knowledge of the delay of the breasting did not correlated with either the profile $(p=0.0857)$ or the place of practice. The knowledge of the first bath was dependent on both the professional profile $(\mathrm{p}=0.0002)$ and the ref-
\end{abstract}


erence level $(p=0.0238)$. Conclusion: The level of knowledge of health professionnels on ENC should be improved. This will involve the integration of ENC in initial training curricula along with an appropriate continuing training policy thereafter.

\section{Keywords}

Essential Care, Newborn, Knowledge, Bamako

\section{Introduction}

Child survival has significantly increased over the past decade with a decline from 75 to 48 deaths per 1000 live births [1]. Unfortunately, this decline was still insufficient to reach the global target of reducing by two-thirds the 1990 infantile mortality rates due to the non-reduction of the neonatal mortality in developing countries [2]. Global neonatal mortality, according to the World Health Organization (WHO), is 19 per 1000 live births and accounts for 47\% of all deaths under five years old [2] [3]. Appropriate application of the WHO recommended systematic care or "essential newborn care" would have prevented two-thirds of these deaths [4] [5]. Essential newborn care combines all gestures (resuscitation, hypothermia prevention, cord care, eye care, vitamin K1 administration, early initiation of breastfeeding and instructions for the first bath) were given to a newborn at birth to optimize his/her chance for survival [5] [6]. In Tanzania, an evaluation had revealed poor health professionals on ENC [7]. It led to massive training that resulted in a $47 \%$ reduction in neonatal mortality [7].

In Mali, despite the efforts of the government and its partners to train health professionals on basic newborn care, the neonatal mortality rate remains still high. According to the latest Demographic Health Survey (EDSM V), it was at 35 per 1000 live births [8]. Could the non-application of the ENC be a possible explanation? Our work was aimed to assess the level of knowledge of the health professionals in the Reference Health Facilities at the second and third levels of the Malian health system pyramid in Bamako, in Mali.

\section{Material and Methods}

The Malian health system is organized as a pyramid with the community health centers (CScom) at the bottom, the reference health centers (CSRef) in the middle and the hospitals and teaching hospitals $(\mathrm{CHU})$ at the top. Our work took place in the six CSRef and at the CHU Gabriel Touré in Bamako, the capital of Mali. It was a multicenter, prospective, transversal descriptive and analytical study from March $20^{\text {th }}$, to April $20^{\text {th }}, 2016$. We included all the accessible health professionals providing neonatal care at the time of the study and who agreed to participate after informed consent was obtained. The interviewed agents were midwives, nurses, general practitioners, residents and specialists in pediatrics and gynecology-obstetrics. We administered a previously pretested survey sheet 
(in Gabriel Touré) to each participant. This pretest ensured that staff had the same understanding of the issues.

The questions intended to test the knowledge level on the resuscitation (indication, aspiration, ventilation, external cardiac massage), prevention of hypothermia (immediate drying, skin-to-skin contact, shift of the first bath), administration of vitamin K1, eye care and the breastfeeding. Answers to the questions were compared to those in the National Essential Newborn Care Training Manual [6] to define good or low knowledge. The data were analyzed with SPSS 20. Frequencies were compared using Epi Info version 6 with a significance level set at $<5 \%$.

\section{Results}

We interviewed 407 health professionals in total with midwives (44.2\%) and nurses (24.3\%), the most represented. The sex ratio was 0.52 . They were not trained in the ENC and had more than five years of professional experience in $58.6 \%$ and $62.1 \%$ of cases, respectively. A low Apgar score was considered by $89 \%$ of staff as an indication for neonatal resuscitation, regardless of profile ( $\mathrm{p}=$ $0.1583)$. They knew a good aspiration technique in $54 \%$, with nurses and midwives more knowledgeable $(\mathrm{p}<0.001)$ at the reference health centers $(\mathrm{p}<0.001)$. They knew the indication and rate of ventilation in $30.2 \%$ and $16.0 \%$, respectively. To $34 \%$ of them, oxygen administration should be systematically during ventilation. General practitioners had the lowest level of knowledge about ventilation ( $\mathrm{p}=0.0063$ for oxygen indication and $\mathrm{p}<0.001$ for the technique). Thirty percent $(30 \%)$ of midwives and $45 \%$ of nurses were aware of the indication for external cardiac massage (ECM). For this technique, knowledge was better among pediatricians and obgyn doctors $(p=0.0260)$. Half of the staff $(50.2 \%)$ knew that immediate ligation and sectioning of the umbilical cord should not be done immediately at birth. More than two-thirds (72\%) were aware of ways to preventing hypothermia. Eye care was known to $90.4 \%$ of agents. The good dosage of vitamin $\mathrm{K}_{1}$ was poorly known by the staff: $18.9 \%$ for midwives, $17.2 \%$ for nurses, $35.7 \%$ for general practitioners, $21 \%$ for physicians in residency. Interviewees had delayed breastfeeding and first bathing in $46.1 \%$ and $46 \%$, respectively (Table 1 and Table 2).

The knowledge of the delay of the breastfeeding did not either correlate with the profile $(p=0.0857)$, or the place of practice. The delay of the first bath was dependent on the profile of the interviewee $(p=0.0002)$ and baseline $(p=$ 0.0238) with the best score for midwives at the CSRef (Table 3).

Table 1. Knowledge of resuscitation andthe profile of the interviewed health professionals.

\begin{tabular}{cccc}
\hline \multirow{2}{*}{ Profile } & \multicolumn{2}{c}{ Good response } & $\mathbf{p}$ \\
\cline { 2 - 3 } & Yes & $X^{2}$ \\
\hline Aspiration technique & & \\
Nurses & $36(36.4 \%)$ & $63(63.6 \%)$ \\
\hline
\end{tabular}




\section{Continued}

\begin{tabular}{|c|c|c|c|}
\hline & & & \\
\hline Midwives & $57(31.7 \%)$ & $123(68.3 \%)$ & $\begin{array}{c}\mathrm{p}<0.001 \\
X^{2}=30.88\end{array}$ \\
\hline General practitioners & $4(9.5 \%)$ & $38(90.5 \%)$ & \\
\hline Residents in Pediatrics & $2(4.6 \%)$ & $41(95.4 \%)$ & \\
\hline Residents in Gynecology-Obstetric & $2(11.8 \%)$ & $15(88.2 \%)$ & \\
\hline Gynecologists-obstetricians & $3(20 \%)$ & $12(80 \%)$ & \\
\hline Pediatricians & $11(100 \%)$ & $0(0 \%)$ & \\
\hline Ventilation technique & & & \\
\hline Nurses & $44(44.4 \%)$ & $55(55.6 \%)$ & \\
\hline Midwives & $116(64.4 \%)$ & $64(35.6 \%)$ & \\
\hline General practitioners & $23(54.8 \%)$ & $19(45.2 \%)$ & $\begin{array}{l}\mathrm{p}=0.0007 \\
X^{2}=23.21\end{array}$ \\
\hline Residents in Pediatrics & $28(65.1 \%)$ & $15(34.9 \%)$ & \\
\hline Residents in Gynecology-Obstetric & $13(76.5 \%)$ & $4(23.5 \%)$ & \\
\hline Gynecologists-obstetricians & $13(86.7 \%)$ & $2(13.3 \%)$ & \\
\hline Pediatricians & $10(90.9 \%)$ & $1(9.1 \%)$ & \\
\hline MCE technique & & & \\
\hline Nurses & $54(54.5 \%)$ & $45(45.5 \%)$ & \\
\hline Midwives & $125(69.4 \%)$ & $55(30.6 \%)$ & \\
\hline General practitioners & $25(59.5 \%)$ & $17(40.5 \%)$ & \\
\hline Residents in Pediatrics & $31(72.1 \%)$ & $12(27.9 \%)$ & $\begin{array}{l}\mathrm{p}<0.001 \\
X^{2}=14.34\end{array}$ \\
\hline Residents in Gynecology-Obstetric & $12(70.6 \%)$ & $5(29.4 \%)$ & \\
\hline Gynecologists-obstetricians & $13(86.7 \%)$ & $2(13.3 \%)$ & \\
\hline Pediatricians & $10(90.9 \%)$ & $1(9.1 \%)$ & \\
\hline
\end{tabular}

Table 2. Knowledge of other ENC components andthe profile of the interviewed health professionals.

\begin{tabular}{cccc}
\hline \multirow{2}{*}{ Profile } & \multicolumn{2}{c}{ Good response } & No \\
\cline { 2 - 3 } & Yes & $\mathrm{X}^{2}$ \\
\hline Dosage of Vitamin $\mathrm{K}_{1}$ & & & \\
Nurses & $17(17.2 \%)$ & $82(82.8 \%)$ & \\
Midwives & $34(18.9 \%)$ & $146(81.1 \%)$ & $\mathrm{p}<0.001$ \\
General practitioners & $15(35.7 \%)$ & $27(64.3 \%)$ & \\
Residents in pediatrics & $9(20.9 \%)$ & $34(79.1 \%)$ & \\
Residents in Gynecology-Obstetric & $5(29.4 \%)$ & $12(70.6 \%)$ & \\
Gynecologists-obstetricians & $7(46.7 \%)$ & $8(53.3 \%)$ & \\
Pediatricians & $9(81.8 \%)$ & $2(18.2 \%)$ & \\
Time for first breast-feeding & & & \\
Nurses & $38(38.4 \%)$ & $61(61.6 \%)$ & \\
\hline
\end{tabular}




\section{Continued}

\begin{tabular}{cccc}
\hline Midwives & $81(45 \%)$ & $99(55 \%)$ & $\begin{array}{c}\mathrm{p}=0.0857 \\
X^{2}=11.09\end{array}$ \\
General practitioners & $15(35.7 \%)$ & $27(64.3 \%)$ & \\
Residents in Pediatrics & $16(37.2 \%)$ & $27(62.8 \%)$ & \\
Residents in Gynecology-Obstetric & $7(41.2 \%)$ & $10(58.8 \%)$ & \\
Gynecologists-obstetricians & $12(80 \%)$ & $3(20 \%)$ & \\
Pediatricians & $5(45.5 \%)$ & $6(54.5 \%)$ & \\
Time for first bath & & & \\
Nurses & $34(34.3 \%)$ & $65(65.7 \%)$ & \\
Midwives & $96(53.3 \%)$ & $84(46.7 \%)$ & \\
General practitioners & $11(26.2 \%)$ & $31(73.8 \%)$ & \\
Residents in Pediatrics & $13(30.2 \%)$ & $30(69.8 \%)$ & \\
Residents in Gynecology-Obstetric & $7(41.2 \%)$ & $10(58.8 \%)$ & \\
Gynecologists-obstetricians & $11(73.3 \%)$ & $4(26.7 \%)$ & \\
Pediatricians & $7(63.6 \%)$ & $4(36.4 \%)$ & \\
\hline
\end{tabular}

Table 3. Knowledge of the interviewed health professionals profile on the essential newborn care.

\begin{tabular}{|c|c|c|c|}
\hline \multirow{2}{*}{ Place } & \multicolumn{2}{|c|}{ Good response } & \multirow{2}{*}{$\begin{array}{c}\mathrm{p} \\
\mathrm{X}^{2}\end{array}$} \\
\hline & Yes & No & \\
\hline \multicolumn{4}{|l|}{ Aspiration technique } \\
\hline CS Ref ${ }^{*}$ & $171(48.0 \%)$ & $185(52.0 \%)$ & $\mathrm{p}<0.001$ \\
\hline CHU Gabriel Touré & $85(72 \%)$ & $33(28 \%)$ & $X^{2}=20.51$ \\
\hline \multicolumn{4}{|l|}{ Ventilation technique } \\
\hline CS Ref & $60(16.9 \%)$ & $296(83.1 \%)$ & $\mathrm{p}=0.3984$ \\
\hline CHU Gabriel Touré & $16(13.6 \%)$ & $102(86.4 \%)$ & $X^{2}=0.71$ \\
\hline \multicolumn{4}{|l|}{ ECM indication } \\
\hline CS Ref & $220(61.8 \%)$ & $136(38.2 \%)$ & $\mathrm{p}=0.6120$ \\
\hline CHU Gabriel Touré & $76(64.4 \%)$ & $42(35.6 \%)$ & $X^{2}=0.26$ \\
\hline \multicolumn{4}{|l|}{ Dosage of Vitamin K1 } \\
\hline CS Ref & $94(26.4 \%)$ & $262(73.6 \%)$ & $\begin{array}{c}\mathrm{p}=0.06098 \\
X^{2}=0.26\end{array}$ \\
\hline CHU Gabriel Touré & $34(28.9 \%)$ & $84(71.1 \%)$ & \\
\hline \multicolumn{4}{|c|}{ Time for first breast-feeding } \\
\hline CS Ref & $68(19 \%)$ & $288(81 \%)$ & $\mathrm{p}=0.1723$ \\
\hline CHU Gabriel Touré & $16(13.6 \%)$ & $102(86.4 \%)$ & $X^{2}=1.86$ \\
\hline \multicolumn{4}{|l|}{ Time for first bath } \\
\hline CS Ref & $163(45.8 \%)$ & $193(54.2 \%)$ & $\mathrm{p}=0.0238$ \\
\hline CHU Gabriel Touré & $40(34 \%)$ & $78(66 \%)$ & $X^{2}=5.10$ \\
\hline
\end{tabular}

${ }^{\star}$ CSRef $=$ reference health centers. 


\section{Discussion}

Training is now one of the major axes of obstetric and neonatal care [9]. Such training should be based on the most available health professionnals in the field. In Mali, nurses and midwives make up to $80 \%$ of the health professionals [10]. They represented $68.5 \%$ of our interviewees. Midwives accounted for half of the staff caring for newborns in maternity hospitals in Togo [11]. Today, multi-level initiatives (local, public and international) are converging to have trained health professionals at the center of reproductive health programs [9]. They should be able to manage optimally perinatal asphyxia, one of the three main causes of neonatal mortality, whose management involves neonatal resuscitation [3] [4]. Most interviewees said that the Agpar score should serve as a benchmark for initiating resuscitation. In the basic health centers in Ethiopia, professionals relied on the baby crying and skin color of the newborn to decide on resuscitation [12]. The Apgar score is a standardized assessment of neonatal adaptation and it measures the success of undertaken resuscitation, but it is not appropriate to deciding on possible therapeutic measures [6] [13] [14] [15]. Since 1999, the WHO has been advocating for the assessment of respiration to initiate appropriate resuscitation procedures [16].

The level of knowledge of resuscitation in these different stages, during our study has to be improved. Oxygen administration should be systematic during ventilation for $34 \%$ of the staff interviewed. All recommendations agree on the initial resuscitation with ambient air and the supplemental oxygen is supplied only when the saturation remains insufficient [6] [13] [14] [15]. According to the WHO, resuscitation can and should be conducted anywhere, including in areas where oxygen is not available [13] [16]. Only nurses, midwives and general practitioners were aware of the aspiration to remove the catheter in $36.4 \%$, $31.7 \%$ and $9.5 \%$, respectively, with a statistically significant difference. Just over half (54.5\%) only had a knowledge of the good ventilation technique. In our study, the level of knowledge regarding resuscitation was similar at both the CSRef and the CHU levels. Gueye M has noticed a poor knowledge level of neonatal resuscitation [17] in the maternity hospitals in Dakar where mask ventilation was well-controlled by $60 \%$ and the fight against hypothermia by $48 \%$ of staff. Only $24 \%$ of the staff at the health center in Cameroon had good knowledge of resuscitation [18]. Gebreegziabher E [12] in Ethiopia, Kim YM [19] in Afghanistan and Jyoti S [20] in India also found low knowledge level of the resuscitation techniques. Ogunlesi AT [21] reported at a public hospital in Kenya that good knowledge level did not guarantee high competence; He found $49.7 \%$ mastery of resuscitation techniques while theoretical knowledge was good at 95.5\%.

According to the WHO, recommended late clamping of the umbilical cord (at one to three minutes after delivery) for all births simultaneously with the introduction of essential neonatal care [22]. The Malian [6] and international [22] [23] guidelines echo the WHO recommendations. During our investigation, this 
recommendation was known by half of the staff. More than two-thirds of the staff surveyed knew how to prevent hypothermia using immediate drying, and skin-to-skin contact. This good knowledge found in many studies [11] [18] [20] [24]. By consensus, the use of the immediate bath is still relevant. Njom AE [24] in Cameroon found that most structures performed baths either immediately at birth or within two hours. Initiation of the first breastfeeding is decisive for the continuation of breastfeeding because attitudes and practices from birth would largely explain the evolution of the rate and duration of breastfeeding [25] [26]. Despite the promotion of breastfeeding through the information campaigns of the general population, training of the health professionals and the implementation of the WHO initiative of "Hospital friendly babies" [27], only one fourth of the interviewees knew the timing to initiate the first breatfeeding regardless of his/her profile and place of practice. Whereas the level of knowledge for eye care was satisfactory, that for the dosage of administration of vitamin K1 was very low into our context. The same observation was made in the maternity hospitals in Dakar where eye care was well-known in $70 \%$ of cases while less than half of providers $(42 \%)$ had a good response regarding the dosage of vitamin $K_{1}$ [28]. In Togo, while recommended eye drops were known to $65.5 \%$ of trained staff in the maternity clinics, only $37.9 \%$ had a good knowledge of vitamin $K_{1}$ treatment [11]. One of the explanations according to Agbéko F [11] would be the recent revision of the recommendations concerning the administration of vitamin $\mathrm{K}_{1}$ by the Ministry of Health in Togo.

One of the limitations of our study was that we did not compare the level of knowledge of those who received ENC training with those who were not trained. Moreover, an observation of the practices could have appreciated the difference between the level of knowledge and the practices.

In most cases, during our survey, neither the profile nor the level of the structure in the health pyramid did influence the level of knowledge on one hand. On the other hand, apart from the pediatricians, midwives were the most knowledgeable about ventilation and external cardiac massage. This was similar to the report from in Togo [11]. Some authors believe that midwives have the advantage of receiving modules on essential newborn care during their initial training [11] [19]. Despite this, Brantuo MN [29] has shown in Ghana that it is the retraining interventions that improve the level of knowledge and skills. Regardless of the initial training, studies agree on the positive impact of specific training on essential newborn care on the level of knowledge of the health professionals [7] [11] [18] [19] [29]. Such training coupled with ongoing on-site refreshers as part of a mentorship program, appear to be the ideal approach to building knowledge and skills on essential newborn care [7] [29] [30].

\section{Conclusion}

Despite training efforts by the health authorities, the knowledge level of the health professionals on essential newborn care in general and birth room resus- 
citation in particular is low. The integration of ENC in the providers' initial training curricula and a good continuing education policy should improve the knowledge and skills of staff on newborn intake and thus contribute to the decline of the newborn's morbidity and mortality.

\section{Conflicts of Interest}

The authors declare no conflicts of interest regarding the publication of this paper.

\section{References}

[1] World Health Organisation (2016) Methods and Data Sources of Child Causes of Death 2000-2015. WHO/HIS/IER/GHE/2016.1.

[2] World Health Organisation (2018) World Health Statistics 2017: Monitoring Health for the SDGs.

[3] World Health Organisation (2018) Global Strategy for Women's, Children's and Adolescents' Health (2016-2030). Rapport Mondial 2018 WHO/FWC/18.21.

[4] World Health Organisation (2015) Pregnancy, Childbirth, Postpartum and Newborn Care: A Guide for Essential Practice.

[5] World Health Organisation (2010) Essential Newborn Care Course (ENCC), Training file.

[6] Ministry of Health of Mali/Save the Children/USAID (2009) National Essential Newborn Care Training Manual (Mali).

[7] Makene, C.L., Plotkin, M., Currie, S., Bishanga, D., Ugwi, P., Louis, H., et al. (2014) Improvements in Newborn Care and Newborn Resuscitation Following a Quality Improvement Program at Scale: Results from a before and after Study in Tanzania. BMC Pregnancy and Childbirth, 14, 381.

https://doi.org/10.1186/s12884-014-0381-3

[8] Ministry of Health of Mali (2014) Enquête Démographique et de Santé, Mali $5^{\text {ème }}$ Phase (EDSM V).

[9] Shetty, P. (2013) More Midwives Needed to Improve Maternal and Newborn Survival. Bull World Health Organ, 91, 804-805.

https://doi.org/10.2471/BLT.13.021113

[10] Ministry of Territorial Planning and Population of Mali and National Institute of Statistics (2015) Annuaire Statistique 2014.

[11] Agbéko, F., Tchagbèlè, O.B., Azoumah, K.D., Ségbédji, K.A.R., Djadou, K.E. and Agbèrè A.D. (2017) Impact of Human Capacity Building on Essential Newborn Care Knowledges in Tog. J Afr Pediatr Genet Med, 3, 10-16.

[12] Gebreegziabher, E., Aregawi, A. and Getinet, H. (2014) Knowledge and Skills of Neonatal Resuscitation of Health Professionals at a University Teaching Hospital of Northwest Ethiopia. World Journal of Emergency Medicine, 5, 196-202. https://doi.org/10.5847/wjem.j.issn.1920-8642.2014.03.007

[13] World Health Organisation (2012) Guidelines on Basic Newborn Resuscitation.

[14] Perlman, J.M., Wyllie, J., Kattwinkel, J., Atkins, D.L., Chameides, L., Goldsmith, J.P., et al. (2010) Part 11: Neonatal Resuscitation: 2010 International Consensus on Cardiopulmonary Resuscitation and Emergency Cardiovascular Care Science with Treatment Recommendations. Circulation, 122, 516-538. 
https://doi.org/10.1161/CIRCULATIONAHA.110.971127

[15] Wyllie, J., Bruinenberg, J., Roehr, C.C., Rüdiger, M., Trevisanuto, D. and Urlesberger, B. (2015) European Resuscitation Council Guidelines for Resuscitation 2015: Section 7. Resuscitation and Support of Transition of Babies at Birth. Resus citation, 95, 249-263. https://doi.org/10.1016/j.resuscitation.2015.07.029

[16] World Health Organisation (1999) Basic Newborn Resuscitation: A Practical Guide. WHO/RHY/MSM/98.1.

[17] Gueye, M., Boiro, D., Faye, P.M., Diagne, R., Gueye, Y., Dieng, Y.J., et al. (2017) Assessment of Knowledge on Neonatal Resuscitation Using "Helping Babies Breathe" (HBB) Program of Maternity Health Caregivers in Dakar. Journal de Pédiatrie et de Puériculture, 30, 219-224. https://doi.org/10.1016/j.jpp.2017.09.001

[18] Monebenimp, F., Tenefopa, M., Mve, K.V. and Kago, I. (2012) Competence of Health Care Providers on Care of Newborns at Birth in a Level-1 Health Facility in Yaoundé, Cameroon. Pan African Medical Journal, 11, 45. http://www.panafrican-med-journal.com/content/article/11/45/full/

[19] Kim, Y.M., Ansari, N., Kols, A., Tappis, H., Currie, S. and Zainullah, P. (2013) Assessing the Capacity for Newborn Resuscitation and Factors Associated with Providers' Knowledge and Skills: A Cross-Sectional Study in Afghanistan. BMC Pediatrics, 13, 140.

[20] Jyoti, S., Jeeva, S., Geetanjli and Poonam, S. (2011) Practices of Auxiliary Nurse Midwives Regarding Care of Baby at Birth. Nursing and Midwifery Research Journal, 7, 110-119.

[21] Ogunlesi, A.T., Dedeke, I.O., Adekanmbi, A.F., Fetuga, M.B. and Okeniyi, J.A. (2008) Neonatal Resuscitation: Knowledge and Practice of Nurses in Western Nigeria. $S A J C H, 2,23-25$.

[22] World Health Organisation (2012) Recommendations for the Prevention and Treatment of Postpartum Haemorrhage: Evidence Base.

[23] Rabe, H., Diaz-Rossello, J.L., Duley, L. and Dowswell, T. (2012) Effect of Timing of Umbilical Cord Clamping and Other Strategies to Influence Placental Transfusion at Preterm Birth on Maternal and Infant Outcomes. Cochrane Database of Systematic Reviews, No. 8, CD003248. https://doi.org/10.1002/14651858.CD003248.pub3

[24] Njom Nlend, A.E. and Beyeme, M. (2015) Audit of Delivery and Essential Newborn Care in Primary Health Facilities in Yaounde. Journal de Pédiatrie et de Puériculture, 28, 233-237. https://doi.org/10.1016/j.jpp.2015.04.005

[25] Scott, J.A., Binns, C.W., Oddy, W.H. and Graham, K.I. (2006) Predictor Factor of Breastfeeding Evidence from a Cohort Study. Pediatrics, 117, 646-655.

https://doi.org/10.1542/peds.2005-1991

[26] Imdad, A., Yakoob, M.Y. and Bhutta, Z.A. (2011) Effect of Breastfeeding Promotion Interventions on Breastfeeding Rates, with Special Focus on Developing Countries. BMC Public Health, 13, S24. https://doi.org/10.1186/1471-2458-11-S3-S24

[27] World Health Organisation (2017) National Implementation of the Baby-Friendly Hospital Initiative 2017. WHO/NMH/NHD/17.4.

[28] Boiro, D., Gueye, M., Fattah, M., Kane, A., NDongo, A., Thiongane, A., et al. (2016) Assessment of Knowledge of Essential Newborn Care (SENN) and Infection Prevention among Maternity Health Staff in Dakar. Revue du CAMES: Science de la Santé, 2, 63-67.

[29] Brantuo, M.N., Cristofalo, E., Mehes, M.M., Ameh, J., Brako, N.O., Boahene, F., et al. (2014) Evidence-Based Training and Mentorship Combined with Enhanced 
Outcomes Surveillance to Address the Leading Causes of Neonatal Mortality at the District Hospital Level in Ghana. Tropical Medicine \& International Health, 19, 417-426. https://doi.org/10.1111/tmi.12270

[30] Opiyo, N., Were, F., Govedi, F., Fegan, G., Wasunna, A. and English, M. (2008) Effect of Newborn Resuscitation Training on Health Worker Practices in Pumwani Hospital, Kenya. PLoS ONE, 3, e1599. https://doi.org/10.1371/journal.pone.0001599 


\section{Appendix}

\section{KNOWLEDGE OF HEALTH PROFESSIONALS ON ESSENTIAL NEWBORN CARE IN DICTRICT OF BAMAKO IN MALI}

\section{SURVEY SHEET}

Nurse year of the diploma:

Midwive $\square$

General practitioner $\square$

Residents in Pediatrics $\square$

Residents in Gynecology-Obstetric $\square$

Pediatrician $\square$

Gynecologist-obstetrician $\square$

Sex: Male $\square$ Female $\square$

Nombre of years of practice

Training on essential newborn care: Yes $\square$ No $\square$

1. Do you the steps of essential newborn care? Yes $\square$ No $\square$

If yes, give the chronological steps

\section{NEWBORN RESUSCITATION}

2. The newborn must be resuscitated if?

He does not breathe Yes $\square$ No $\square$

He has irregular breathingYes $\square$ No $\square$

He is pale Yes $\square$ No $\square$

He is cyanotic Yes $\square$ No $\square$

He is hypotonic Yes $\square$ No $\square$

He has a heart rate less than 100/minute Yes $\square$ No $\square$

Apgar score is low Yes $\square$ No $\square$

I don't know Yes $\square$ No $\square$

3. Do you know the stages of resuscitation of the newborn? Yes $\square$ No $\square$ If yes, quote them

4. We suck the nostrils and then the mouth. Yes $\square$ No $\square$ I don't know $\square$

5. The aspiration is made:

Only when the probe is removed and not when introduced Yes $\square$ No $\square$ At the introduction and removal of the probe Yes $\square$ No $\square$

Only at the introduction of the probe Yes $\square$ No $\square$ 
I don't know Yes $\square$ No $\square$

6. To suck the secretions from the nostrils, the probe is introduced:

To the Oropharyngeal Crossroads Yes $\square$ No $\square$

At about $3 \mathrm{~cm}$ and removing the probe quickly Yes $\square$ No $\square$

At about $3 \mathrm{~cm}$ and removing the probe slowly Yes $\square$ No $\square$

I don't know Yes $\square$ No $\square$

7. A newborn who screams and is well colored does not need to be sucked.

Yes $\square$ No $\square$ I don't know $\square$

8. At what rate is the mask ventilation?

30 per minute Yes $\square$ No $\square$

40 per minute Yes $\square$ No $\square$

60 per minute Yes $\square$ No $\square$

100 per minute Yes $\square$ No $\square$

I don't know Yes $\square$ No $\square$

9. The mask must cover:

Only the nose Yes $\square$ No $\square$

Nose and mouth Yes $\square$ No $\square$

Only mouth Yes $\square$ No $\square$

Nose, mouth and eyes Yes $\square$ No $\square$

I don't know Yes $\square$ No $\square$

10. Mask ventilation begins if the heart rate is below:

60 beats per minute Yes $\square$ No $\square$

100 beats per minute Yes $\square$ No $\square$

150 beats per minute Yes $\square$ No $\square$

I don't know Yes $\square$ No $\square$

11. For ventilation, oxygen should always be used.

Yes $\square$ No $\square$ I don't know $\square$

12. We appreciate the efficiency of ventilation by:

Raising the ribcage symmetrically Yes $\square$ No $\square$

Re-staining Yes $\square$ No $\square$

Urine emission Yes $\square$ No $\square$

I don't know Yes $\square$ No $\square$

13. The cardiac massage starts if the heart rate is lower than:

60 beats per minute Yes $\square$ No $\square$

100 beats per minute Yes $\square$ No $\square$

150 beats per minute Yes $\square$ No $\square$

I don't know Yes $\square$ No $\square$

14. Cardiac massage should always be coupled with ventilation.

Yes $\square$ No $\square$ I don't know $\square$

OTHERS NEWBORN CARE

15. Do you know how to maintain the temperature of the newborn? Yes No $\square$

If yes, quote them 


\section{The newborn is dried:}

Immediately at birth Yes $\square$ No $\square$

A few minutes after birth Yes $\square$ No $\square$

After the umbilical cord section Yes $\square$ No $\square$

I don't know Yes $\square$ No $\square$

17. Do you know the dose of vitamin $\mathrm{K} 1$ to administer? Yes $\square$ No $\square$

If so, what is the dose?-

18. The ligature and the section of the cord should be done immediately after birth.

If the mother is HIV positive Yes $\square$ No $\square$

In case of perinatal asphyxia Yes $\square$ No $\square$

In all situations Yes $\square$ No $\square$

19. Eyes care is done.

Immediately at birth Yes $\square$ No $\square$

After breastfeeding and within one hour after delivery Yes $\square$ No $\square$

24 hours after childbirth Yes $\square$ No $\square$

I don't know Yes $\square$ No $\square$

20. What antimicrobial (s) is (are) recommended for eye care?

21. When to initiate the first feed if the newborn is well?

22. What is the minimum time to wait for the first bath of the newborn? 